\title{
Switiching Roles in Pursuit of Democracy in Uganda: the performance of civil society and media in the absence of political opposition
}

\section{Sam S. Mutabazi}

\section{(2) OpenEdition Journals \\ Electronic version \\ URL: https://journals.openedition.org/eastafrica/584 \\ DOI: 10.4000/eastafrica.584 \\ ISSN: 2790-1076 \\ Publisher \\ IFRA - Institut Français de Recherche en Afrique}

\section{Printed version}

Date of publication: 1 September 2009

Number of pages: 95-115

ISSN: 2071-7245

\section{Electronic reference}

Sam S. Mutabazi, "Switiching Roles in Pursuit of Democracy in Uganda: the performance of civil society and media in the absence of political opposition", Les Cahiers d'Afrique de l'Est / The East African Review [Online], 41 | 2009, Online since 07 May 2019, connection on 09 December 2021. URL: http:// journals.openedition.org/eastafrica/584 ; DOl: https://doi.org/10.4000/eastafrica.584

This text was automatically generated on 9 December 2021.

Les Cahiers d'Afrique de l'Est / The East African Review 


\title{
Switiching Roles in Pursuit of Democracy in Uganda: the performance of civil society and media in the absence of political opposition
}

\author{
Sam S. Mutabazi
}

\section{Introduction}

1 More than twenty years of inhibition of activities of political parties in Uganda has had a great impact on their performance. It is more than two years since they were allowed to organize but their impact as a vibrant political opposition is yet to be felt. Two important actors therefore took the position of highlighting the excesses and failures of government, a role that would ordinarily be played by political parties or opposition. The media and civil society organizations (NGOs) have been instrumental in shaping public opinion and rallying the masses about the shortcomings of President Yoweri Museveni's government. Even after the introduction of multiparty democracy in 2005, civil society continues to wield a lot of influence in determining the political trend of the country.

2 The growth in political party strength after the re-introduction of multiparty democracy has generally tended to be positive. Though political space is not duly competitive especially due to deliberate restrictive government maneuvers, it is anticipated that more gains will be realized as the public embraces multiparty democracy and shuns individual merit systems. This paper analyzes how civil society and media have shaped the political trend in Uganda in the absence of an official opposition. We compare government and peoples attitudes towards multiparty democracy and explore how the transformations after the introduction of a multiparty 
system are influencing institutional development and democratic governance in Uganda. The paper constructs and defends a blended analytical approach to evaluation of attempts by political parties to fight for increased space. It takes a historical as well as current approach in analyzing the trend of events in Uganda's movement in the democratic path and what it has achieved so far.

\section{Genesis of multiparty democracy in Uganda}

3 In 1967, Uganda got a Republican constitution, which maintained a multi-party system of Government. The Constitution stipulated that after a general election, the Party with greatest numerical strength of the elected members would form the government. Further, under the Constitution, members of the National Assembly were deemed to have been elected for a term of five years. Parliament under the Republican Constitution was the Second Parliament of Uganda. The elections provided for under this new Constitution were never held due to the military coup which took place in January 1971. From 1971 to 1979 the Uganda Parliament was in abeyance, having been suspended by Field Marshall Idi Amin Dada, the then military leader.

4 Following the overthrow of the military regime in 1979, Uganda got an Interim Parliament known as the National Consultative Council. It was initially composed of 30 members who were elected at Moshi, Tanzania, but was later in 1979 expanded to 120 members. The Interim Parliament continued to be the Supreme Legislative Body until the general elections that were held in 1980. This was the Third Parliament of the Republic of Uganda.

When the NRM usurped power in 1986, they introduced a quasi parliament mainly consisting of ministers and NRA apologists. In February 1989, new legislation recognized the appointments of the original 38 members of the NRC and provided for the enlargement of the NRC through the election and appointment of additional members. Each county and each district would elect one representative (only women could be candidates for district representative). In addition, one or more of the representatives would be elected by municipalities, depending on the size of their populations. The original parliamentary representatives were legitimized by their participation in the guerrilla struggle, not by elections. Although political figures that had not been part of the NRM or NRA during the war were later appointed to the NRC and in 1989 elected to it, the original NRC members continued to occupy a privileged position. They did not have to stand for election to the NRC. In addition, their special status was formalized in February 1989 with the creation of the National Executive Committee (NEC), a standing committee of the NRC, to contain these original members plus one elected member from each district and ten members appointed by the chair of the NRC from among its members. The NRC was later to transform into the Constituent Assembly (CA) that formulated the 1995 constitution. In 1996 a fresh parliament was constituted under the newly promulgated constitution that barred individuals from contesting for office on a political party platform. The restriction of political party activities was therefore achieved at this stage in a semi-legal fashion. Though unacceptably and unfathomably inconceivable especially in the eyes of international legal instruments, this obnoxious law was to be applied to all political opposition in Uganda for the next ten years or so in spite of strong resistance from both within and outside the country. 
6 A referendum was held in March 2000 on whether Uganda should retain the Movement system, with limited operation of political parties, or adopt multi-party politics. Although $70 \%$ of voters endorsed retention of the Movement system, the referendum was widely criticized for low voter turnout and unfair restrictions on Movement opponents. Museveni was re-elected to a second five-year term in March 2001. Parliamentary elections were held in June 2001, and more than $50 \%$ of contested seats were won by newcomers. Movement supporters nevertheless remained in firm control of the legislative branch. Observers believed that the 2001 presidential and parliamentary elections generally reflected the will of the electorate; however, both were marred by serious irregularities, particularly in the period leading up to the elections, such as restrictions on political party activities, incidents of violence, voter intimidation, and fraud.

\section{The Movement political system}

7 By Legal Notice No. 1 of 1986, the NRM, which formally suspended party activity, amended the 1967 Constitution and among other things vested the NRC with supreme authority of the Government and in particular, the legislative powers of the legislature. In essence, an individual merit system was introduced in earnest at this particular time. Unlike multiparty democracy which brings together people of the same leaning wishing to achieve a common goal, the movement system allowed individuals to offer varied opinions and ideas about different aspirations which makes cohesion at group level totally disunited. In simple terms, the movement system can never promote or consolidate patriotism because there are no common goals under this so called system of governance.

The Movement political system was defined as broad-based, inclusive and nonpartisan with the following principles:

- (a) Participatory democracy;

-(b) Democracy, accountability and transparency;

- (c) Accessibility to all positions of leadership by all citizens;

- (d) Individual merit as a basis for election to political offices.

The person who benefited most from the movement system was President Yoweri Museveni who became larger than the system itself. The system made him more powerful than any other institution or groups of people and he wanted the status quo to remain since this would guarantee his stay in power. One of the greatest weaknesses of an individual merit system is that it effectively divides the population since individual politicians fight to outshine each other for recognition by the population and the president who rules like a king. Recent research in public opinion suggests that citizens have a range of views, not a single fixed one. As a consequence, persuasive communication can be highly relevant. Therefore, much depends on the role of the parties in persuading potential voters. Particularly, if a person has little prior information, then information reaching him will have a large effect (Akkermann, 2003)

\section{Regulation of political organizations}

Political party activities were restricted by Article 269 which stated that: 
On the commencement of this Constitution and until Parliament makes laws regulating the activities of political organizations in accordance with article 73 of this Constitution, political activities may continue except-

(a) Opening and operating branch offices;

(b) holding delegates' conference;

(c) holding public rallies;

(d) sponsoring or offering a platform to or in any way campaigning for or against a candidate for any public elections;

(e) carrying on any activities that may interfere with the movement political system for the time being in force.

11 Article 269 was clearly not in consonance with Article 29 (a, b, d, and e) which states that:

29. (1) Every person shall have the right to-

(a) freedom of speech and expression, which shall include freedom of the press and other media;

(b) freedom of thought, conscience and belief which shall include academic freedom in institutions of learning;

(d) freedom to assemble and to demonstrate together with others peacefully and unarmed and to petition; and

(e) freedom of association which shall include the freedom to form and join associations or unions, including trade unions and political and other civic organizations.

Whereas Article 75 says Parliament shall have no power to enact a law establishing a one-party state, many people have argued that the movement was nothing other than a political party that sought to legitimize itself using ambiguous laws. It managed keep political parties in abeyance for 20 years because it was acting in a semi-legal fashion. In real terms, political parties, as they are known worldwide are supposed to recruit members, open branches, address rallies and field candidates. Other people have argued that President Yoweri Museveni would have completely banned political parties in Uganda had it not been the fear that this would attract too much condemnation from the west. Although parties were recognized in the constitution, they did not serve any purpose being constantly referred to in name. In effect the NRM government managed to rule Uganda without any opposition, not because there was none but because the state used its might to make the purpose of opposition appear irrelevant and less useful. To date president Yoweri Museveni still thinks that the NRM has been the best thing that ever occurred to Uganda as a country and that it has not and will not make any mistake that can warrant the opposition to point them out.

If ordinary citizens cannot exert a relatively high degree of control over leaders, then the minimal threshold of democracy has not been reached in sub-Saharan Africa. As Robert Dahl has written, Africa is a place where demand for democracy exceeds supply. Presidents are shifting power away from the people and other arms of government. Larry Diamond contends that the political struggle in Africa remains largely a conflict between the rule of law and the rule of a person. Posner and Young point to incumbent's losses at the polls in Africa in recent times and attempts to erase term limits, most notably in Nigeria. They however argue that while the holding of regular multiparty elections and the occasional defeat of incumbents are significant trends, the struggle to cross the frontier from personal rule to rule-based governance is still far from over in most of Africa.

14 Life is about choices. The more the choices, the more meaningful and fulfilling life becomes. Most governments in Africa are not comfortable allowing the people they 
rule to make choices about governance and democracy. Human nature is that most people, including leaders are not comfortable when they are criticized for their shortcomings. The role of the opposition is to critique government programmes and policies and provide an alternative view on how an issue ought to have been handled. Governments all over Africa have praise singers. Not criticizers. They are therefore either mindfully or otherwise narrowing the choices of the people by dictating that citizens must support the government in power irrespective of whether such a government is living up to the challenge or not.

Systems of personal rule have continued to clash with institutions intended to give expression to the popular will. The democratic upsurge of the early 1990s, along with the play of political and socio-economic forces are too complex to capture under the rubric of transition paradigm. The resumption of competitive party politics and the shift from static to market oriented economic systems heralded a reconfiguration of powers whose outcomes could not be predicted. Today, the evolution of this reconfiguration remains uncertain as illiberal regimes cling to power (Berendsen, 2008). It is widely believed that as President Yoweri Museveni seeks to hold on to power, elections in Uganda are likely to continue to being unfair, inefficient and barely credible.

\section{Multiparty democracy}

Political parties form a cornerstone of a democratic society. They represent the interest of a particular group with a view to popularizing certain beliefs and ideas which are believed to be better options to transform a given society or country. Parties which are well-managed provide the best avenue for democratic governance and growth of a nation through a system that is not easy to manipulate by those in authority.

17 For political parties to meaningfully deliver, they are supposed to be democratic from within and should allow free debate. Most importantly they must cultivate a culture of constitutional governance. It is a great challenge for parties to become democratic because they have many interests and targets. But this alone cannot be the withholding factor. Whereas most political parties in Uganda have well-drafted constitutions as their supreme guiding document, these constitutions have not been adequately implemented to the satisfaction of both party members and Ugandans at large. If political parties are not democratic, it follows without question that they will be worse when they assume power. A well-meaning political party would never postpone constitutionalism and democracy within its ranks and hope to rectify this anomaly when it takes over power. At that time it may be too late to right the wrongs that were committed along the way. Democracy is like any living creature. It needs to be natured and practiced by those who agitate for it before it can mature.

Democracy is an avenue by which people's aspirations for a better future can be expressed and claims for redress made (Prempeh, 2008). The French and the British consider party democracy as a central tenet of good governance philosophies. It is a core value that orientates their political attitudes and defines their identity (Faucher, 2003). On the contrary, governments in Africa have a tendency of deliberately weakening institutions, particularly opposition political parties. They are aware that well-functioning, vibrant and strong institutions would seriously check all undemocratic tendencies of government. 
19 For any society, the transition from authoritarian state to egalitarian government implies major social and economic upheaval-especially when the forces of opposition remain powerful (Ihonvbere, 1998).

Democracy is about competition and choices. It places a sense of responsibility on those in power to exercise their authority responsibly with the people they govern at the centre of expected benefits of every action and programme undertaken by government.

Before 1787-89, most political thinkers would regard democracy as consisting only of the power of the people, an illusion that lasted throughout the $19^{\text {th }}$ and $20^{\text {th }}$ centuries. Yet, at the same time democracy has evolved into a composite regime that combines the rule of the people with the rule of the law. Constitutionalism-that is the development of counterweights to the unbalanced supremacy of the people-developed rapidly after the Second World War in European democracies under the influence of the American model. Enforceable human rights, constitutional courts, the territorial and functional division of powers, all became key features of European democracies. Although there is a broad consensus that democracy is founded on these pillars, there is disagreement over the correct balance between these components of democracy (Akkerman, 2003).

Current measures of levels of democratization are often mistaken to be an indication of the "quality" of democracy in a more comprehensive and normatively more demanding sense. The same is true for some of the current criteria and indicators of "good governance" (Berg-Schlosser, 2004). Although there is not yet any agreeable form of democracy for all countries in the world, multiparty democracy is widely seen as one of the best forms given its many advantages compared to other forms of democracy practiced in various countries all over the world.

Unlike the cases of Kenya and Tanzania, the democratic opening in the 1990s did not involve a shift from a single party to a multiparty system. Rather, it involved a shift from the pseudo-multiparty system under Milton Obote's government to what the government called a Movement system. Until a constitutional referendum in July 2005, only one political organization, the Movement (also called the National Resistance Movement) was allowed to operate. The President, who also chairs the Movement, maintained that the Movement was not a political party, but a mass organization that claims the loyalty of all Ugandans. Until the 2005 referendum, the 1995 constitution required the suspension of political parties while the Movement organization is in governance. Other political parties could exist but are prohibited from sponsoring candidates and holding meetings. Mueseveni maintained that the Movement was not a political party, but a mass organization that claims the loyalty of all Ugandans.

With the NRM's accession to power, the very existence of the old political parties, particularly the DP and the UPC, became an issue. The old parties were permitted to maintain their headquarters and to issue statements but could not hold rallies or campaign on behalf of candidates for RC elections. This decision stirred fears among adherents of the old parties that the NRM intended to consolidate its hold on power and eventually eliminate them.

Parties were finally freed by the Constitution (amendment) Act, 2005 which came into force on 30 September 2005 amended Article 72 of the Constitution thus: "Any person is free to stand for an election as a candidate, independent of a political organization or political party. Parliament, shall by law, regulate the manner of participation in and financing of 
elections by individuals seeking political office as independent candidates." However, the overall sentiment from the skeptics after the reintroduction of multiparty democracy is that no real change took place and that the transition is largely cosmetic. They maintain that in reality the movement philosophy and ideology reigns and there has been no fundamental shift in value systems. As a result, party politics will remain peripheral, only tolerated as a necessary evil (Larok, 2007). disliked most when it is at its best. Or, at least, that seems to be so in the often rocky relationship between the media and those in authority, whether in government or big business (News Manual Online, 2008). Very few governments like a free and unrestrained media. They dislike the media when it criticizes their policies or performance; they despise journalists when they voice opposing views and they absolutely loath them when they expose corruption in their own ranks. Ironically, politicians in opposition usually love the media when they are doing their best work. It is only when they enter into government that these same politicians suddenly see how awful the media really are.

31 We live in a society today where the media plays an alarmingly big part in how we consider our affairs and how our opinions are formed. The media has helped Uganda grow its democracy by emphasizing on issues that may once have been considered strictly political. Due to media intervention, Ugandans now consider politics differently. Under ordinary circumstances, opposition political parties are supposed to act as whistle blowers about things that go wrong within government. Their allies in this endeavour are supposed to be the media. Because political parties were too weak to pursue this role, it was the media that fed the weak opposition on the goings-on in 
government. The media thus became both the de facto opposition and the watchdog which is supposed to be its original role.

In a report by USAID titled "The role of media in democracy: a strategic approach," it is argued that since the media depends on opposition parties for sources which are critical of the government, viable minority protected opposition parties are institutions that may support the development of an independent media. Opposition parties also help to institutionalize a culture where critical views are tolerated. While some governments view this activity as destabilizing, it may be just the opposite since where press freedom is denied, the opposition may turn to more violent forms of expression and protests.

Media development is supposed to be about the structural or institutional view of what it can achieve. The case to be made is that it should be emphasized that the set of institutions that are likely to promote responsiveness and accountablility must include a structural or institutional view of the media. It is the "fourth-estate-of-the-realm" view. Particularly, when one is interested in improving the quality of governance, there ought to be a free, plural and independent media system. It should be seen in the same way as an independent judiciary, legislative bodies, free and fair elections, vibrant civil society and so on (Odugbemi, 2008).

The media was Uganda's basic resource for all the news concerning opposition politics during the era of the Movement political system. The opinion expressed by the press influences the opinion adopted by the public. Lastly, the issues the media deem important help set the national agenda. The most basic way the media influence public opinion is by offering knowledge about government decisions and access to government information. The press delivers the raw information to the nation daily, which in turn forms into opinions. Without the media it would take the public longer to become educated about governmental proceedings. The media send messages across the nation.

Although the NRM government has liberalized the media industry in Uganda, there is a level beyond which government is not ready to allow them to transcend. President Yoweri Museveni has quite often threatened to close some media houses and indeed some have been clamped down which has resulted into self-regulation and selfcensorship in order for such media to remain in the good books of government. Print media remains the most vibrant agitator of democratic governance. Currently there are four major dailies in Uganda namely The New Vision, Daily Monitor, Red Pepper and Bukedde, a Luganda government-owned but largely independent newspaper. There are more than $50 \mathrm{FM}$ radio stations and up to seven television stations in and around Kampala alone. The media has provided a platform to both opposition and government representatives to discuss issues. In some cases however, when government is caught in serious breach of people's expectations, and when some of its actions are indefensible to Ugandans, it chooses to keep mum. In other instances, instead of government coming out to explain to the public, it has gone a step further by threatening to close down media houses that host opposition figures. The opposition leader Retired Colonel Dr. Kiiza Besigye has been barred from addressing people on various radio stations and televisions including the state owned UBC TV.

36 The media has without doubt played a significant role in shaping and contributing to the few gains so far achieved since the reintroduction of multiparty democracy in Uganda. Some of the print media have even been branded opposition mouthpieces 
because of their consistent reporting about government excesses. Although radio and TV play a major role in disseminating information, including that on democracy and governance, print media remains the strongest medium of exchange of political discourse especially among the elite population in most urban areas.

President Yoweri Museveni knows journalists can use the power of the pen to influence critical issues in the public domain which would systematically erode his popularity. He has therefore over the years developed a scheme to woo and offer better opportunities to critical journalists to work in different government departments, hence silencing them. Because journalism is not a well-paying profession, particularly in Uganda, the journalists often take up the "juicy" jobs offered which automatically means that they are politically silenced or if they are to express themselves, they normally toe the party line. It is worrying to see how many resources the government is willing to commit to buying-off journalists, which means the media will remain neutral or not very critical of government. Whether this is practically possible is highly debatable. What seems to be obvious is that the current administration led by Yoweri Museveni is buying time in order to stay in power with as little criticism as possible.

The strongest advocate of political reform from the media has perhaps come from the Daily Monitor that took on the role of the opposition during the period when political parties were not allowed to operate. Others are The Weekly Observer and the now defunct Crusader Newspaper. A few others including the government mouthpiece, The New Vision and the Red Pepper have to some extent also helped to raise important political debates but not to the standards of the former. Government has often intimidated the media to silence it. It has been alleged that, sometimes, state operatives go to newsrooms to stop newspapers from publishing certain stories. The Monitor was closed in 2002 for 10 days for allegedly publishing false news. Its sister FM radio station was closed as well in 2005. Government tried severally to block the notorious website, www.radiokatwe.com, which was publishing nerve-wracking stories about government and people associated with it. The authenticity of some of these stories is doubted but nonetheless, government felt uncomfortable with most of the publications which made some people to believe that some issues raised by Radio Katwe could have been true after all. Otherwise, why would government go to the extent of blocking the website?

It is true that there are some careless journalists who publish non-researched work which enrages the government. Some of the stories are completely out of context in terms of truth. The explanation for this, however, is that government is not in any way liberal with the way it releases information which leaves the media with only one option-speculation. Although readership of print media is still very low in Uganda as compared to Kenya, it nonetheless has almost the same impact if not more. This can be explained by the enthusiasm with which the elite public discusses topical issues especially those carried on front pages of major newspapers. The New Vision circulates an average of 35,000 copies daily compared to Daily Nation, the largest newspaper in East Africa which has a circulation of over 150,000 copies per day.

Media freedom, even in well established democracies, has been put to great challenges by the state and this means that it has to work hand-in-hand with other actors such as the political opposition and civil society to stave off negative government reaction. As the old saying goes, one good turn deserves another. The media stood with the opposition when they were not allowed to freely operate. Now that parties have been 
freed, the opposition needs to stand by the media to further expand democratic freedom in Uganda.

\section{The NGOs and their role in democratic governance}

41 The end of long-standing authoritarianism in the late twentieth century provoked a global resurgence of civil society in the Third World that has driven scholars increasingly to ask how revitalized social movements impact democratic progress. effects. (Suh, 2008).

In a struggle for democratic reform and transformation, key players stand out. These are civil society organizations and the media that have sought to keep government on its toes in demanding fair laws and a level field for all political actors to be heard. These include organizations such as The Uganda Joint Christian Council (UJCC), Foundation for Human Rights Initiative (FHRI), Amnesty International, Human Rights Watch, International Republican Institute (IRI).

Hennie Kotze agues that the role of the civil society in the African democratization process has been severely compromised. He quotes Clapham who wrote more than a decade ago,

"Sustained rather than sporadic activism is required, and the nascent civil societies are largely too weak to do the job, not only in Nigeria and Zaire (where transitions have become stalemated) and in Burkina Faso, Cameroon, Kenya, and Togo (where transition outcomes are still ambiguous), but also in Benin, Malawi, and South Africa (where transition outcomes have been more clearly successful). In nearly every case, the ability of civil society to help deepen democratic governance and put it beyond reversal remains in serious doubt."

I do not agree with Hennie because of the fact that governments in Africa have been deliberately keeping civil society weak, including putting up stringent laws like those in Uganda such as the NGO Registration Act.

Civil society is a self-appointed ombudsman of good governance and democratic accountability in every country. An organized and strong civil society has the capacity to cause fundamental changes in the development process of a country and specifically on formation and sustenance of a foundation base for good governance and democracy. From good governance, the country would reap the benefits in form of harmonized development based on justice freedom and equity for its entire people. Countries with a strong civil society have demonstrated that their citizenry enjoy more democratic freedoms than those where civil society is weak. The civil society-both local and international-has played a key role in ensuring that political parties and the opposition in Uganda are strengthened to provide a viable alternative government in waiting. Civil society is a strong force in mobilizing masses. They have the advantage of time and potential of mobilizing resources both from within and outside the country to create an impact in terms of political accountability and expediency for the people by government.

As for "political" activities, Ugandan NGOs are not permitted to belong to any political group. They cannot directly or indirectly support a political candidate running for office. NGOs can actively participate in the election process through conducting educational seminars on current topics of political concern, including understanding the platform of various candidates. Moreover, organizations are allowed to engage in 
monitoring and observing the electoral process, documenting the flaws in elections, cooperating with the Electoral Commission, and proposing improvements to the electoral process. In the past, organizations have supported candidates in their bids to challenge election results.

The NGO Registration Act and its implementing regulations allow the Government of Uganda to exercise considerable control over the operation of NGOs. An NGO is prohibited from operating in Uganda unless it has registered with the National Board of Non-Governmental Organizations (Board). (NGO Registration Act 2 [1]). When issuing the certificate of registration to the NGO, the Board may grant the registration subject to conditions or directions "generally as it may think fit to insert in the certificate, and particularly relating to: (a) the operation of the organization; (b) where the organization may carry out its activities; and (c) staffing of the organization" (NGO Registration Act 2 [2]).

The limitation arises when government is not comfortable with the work of NGOs because it is aware of the power they yield. According to Human Rights Watch Backgrounder Report 2001, The NGO board's powers are extensive. In granting registration, it can specify "conditions or directions" for the NGO concerning its "operations" (a term that is not defined in the law), where it may carry out its activities, and its staffing. Once registration has been granted, the NGO board has further powers enabling it to "guide and monitor organizations in carrying out their services," and to summarily revoke an NGO's registration if the NGO is considered to have contravened any of the "conditions or directions" that the NGO board set when approving its registration. All these are deliberate attempts by government to keep the civil society weak and incapable of challenging government on its shortcomings.

The current law provides for an excessive degree of state control and interference in the activities of NGOs. The mandatory registration requirement means that the government, through the NGO board, has full powers to determine which NGOs are permitted to operate. NGOs that wish to engage in legitimate activities within the community can be prevented from doing so legally, if the government disapproves of them, by being refused registration. NGOs may also be required to carry on their activities under conditions or in locations not of their choosing, or not to employ or to dismiss particular individuals, such as known government critics or opponents, from their staff. Having obtained registration, NGOs may be summarily closed down on illdefined grounds of "public interest" by order of the NGO board. In such case, the NGO board is not even required to provide detailed reasons or disclose evidence in support of its decision to revoke registration, and the NGO is denied recourse to the courts or an independent judicial body. It is only permitted to appeal to the minister responsible for appointing the NGO board.

The perception that NGOs that have obtained registration may be subject to continuous and potentially intrusive monitoring by the state is heightened by the presence of state security representatives on the NGO board. This, understandably, may lead NGOs to exercise a degree of self-censorship, including on important issues of public concern. Under the twin threat of surveillance and de-registration, it would be surprising if some NGOs did not feel obliged to adopt more cautious policies and practices than they would wish, and to steer clear of activities that, while entirely legitimate, could be controversial or politically sensitive, and incur government displeasure.

51 Civil society works on the demand side of the political equation. They engage in honest and open political dialogue with government on the state of democracy. They also 
make sure the state can live up to the expectations and demands of the governed. Many citizens judge their governments by its ability to provide basic services such as security, health and education. Civil society is thus, aware that democracy plays an important role in provision of basic services to the people. In a country where political opposition is strong, the work of civil society is less because the objectives of the two, though dissimilar in nature, are the same in character in a sense that they both fight to put in place an accountable government that is democratic in nature and transparent in its transactions. The ideal situation would be to have a strong opposition while at the same time having a strong civil society which would mean that the two would work together to form an even a stronger coalition that can easily suggest alternative policies for government and put it to task whenever possible.

Civil society and the media is credited for enhancing the access of desperate segments of the citizenry to the governance and development process. Civil society can contribute to improvement of internal democracy and social accountability of development programmes and enhance popular participation in such processes. It is important that both civil society and the media work hand in hand to promote the noble cause of promoting democracy and development. Where government tries to limit their spaces, each of the two should defend the other in order to create a strong force. In the long run, it will be difficult for government to attack any of the two because it will fear the wrath that may come with its undemocratic actions.

\section{Conclusion}

The movement system has had a great impact on political trends in the country and it is not likely to be erased in the short run. The individual merit system was an ideal situation that is not practical in real terms. Although its ideals are fancy and enticing to a group of people one may term as "political novices", it is impossible to enforce the system without trampling on the rights of the people. It takes away the common values of humanity by promoting individualism at the expense of social cohesion. The existence of a healthy, respected and respectful opposition is a common feature of democratic politics. For a democracy to function properly, it needs an opposition to provide political contestation and electoral competition, thus limiting the power of the ruling party. In other words: no opposition-no democracy (Kotzé, 2008). The main obstacle to democratic progress in Africa therefore seems to be the resistance of autocratic leaders to give way to opposition leaders through free and fair elections. Most African countries have an excessively strong presidency, with opposition parties being "plagued by weak organizations, low levels of institutionalization and weak links to society." It will take a lot convincing to tell governments that strong opposition political parties are good for their countries. Leaders of most states, especially in developing countries, believe that policies are good only when they favour such leaders. The media and civil society have been instrumental in pushing for increased political freedom. The little gains so far achieved can be attributed to their efforts which should not be underestimated given the circumstances they were operating in. 


\section{BIBLIOGRAPHY}

Akkerman, Tjitske (2003). Populism and Democracy: Challenge or Pathology? Palgrave: Macmillan.

Berg-Schlosser, Dirk (2004). "Indicators of Democracy and Good Governance as Measures of the Quality of Democracy in Africa: A Critical Appraisal.” Acta Politica 39 (3).

Berendsen, Bernard, ed. (2008). Democracy and development. Amsterdam: KIT Publishers.

Byrnes, Rita, ed. (1990). Uganda: A Country Study. Washington: GPO for the Library of Congress.

Centre for Democracy and Governance (1999). The role of media in democracy: a strategic approach. Washington D.C.: USAID.

Core document forming part of the reports of the States Parties: Uganda (1996). Geneva: Office of the United Nations High Commissioner for Human Rights.

Faucher, Florence-King \& Treille, Éric (2003). Managing Intra-party Democracy: Comparing the French Socialist and British Labour Party Conferences. Palgrave: Macmillan.

Gianfranco Pasquino (2008). "Multiparty Democracy: Elections and Legislative Politics.” West European Politics 31 (3): 625-626.

Ihonvbere, Julius (1998). Economic crisis, civil society and democratization: The case of Zambia. Trenton (NJ): Africa World Press.

Katz, R. \& Mair, P. (1995). "Changing models of party organization and party democracy: the emergence of the cartel party." Party Politics 1 (1): 5-28.

Kotze, Hennie (2008). "Opposition party support in Africa: An Elite-mass analysis, Government and opposition." Government and Opposition 43 (3): 454-485.

Kwasi Prempeh, H. (2008). “Progress and Retreat in Africa: Presidents Untamed.” Journal of Democracy 19 (2): 109-123.

Larok, Arthur (2007). "Civil society and politics: A niche for civil society organizations in the reviewed Multiparty System in Uganda." National NGO Forum working paper, December.

Suh, Doowon (2006). "Civil Society in Political Democratization: Social Movement Impacts and Institutional Politics." Paper presented at the annual meeting of the American Sociological Association, Montreal Convention Center, Montreal, Quebec, Canada, August.

\section{INDEX}

Geographical index: Uganda | Ouganda 